\title{
PLASMA PROTEIN VALUES IN INFANTS
}

\author{
BY
}

EVELYN M. HICKMANS, M.Sc., Ph.D., ETHEL FINCH, M.Sc., and EVA TONKS, M.Sc. (From the Children`s Hospital, Birmingham)

There are only a few reports in the literature dealing with the amount of plasma or serum protein during the neonatal period; nor is there agreement as to the normal amount of protein in children under one year of age. Several workers have stated that the serum of infants contains considerably less protein than that of adults and that there is a gradual increase in the concentration of the serum proteins throughout the first year of life, at the end of which time adult values are reached.

Ray and Phatak (1930) give a value of $7.0 \mathrm{gm}$. per 100 c.c. for total protein in new-born infants (twenty cases). According to Kylin (1932) the range of values for the serum protein of children under two years of age is 4.6 to $6.5 \mathrm{gm}$. per 100 c.c. Darrow and Cary (1933), using the Kjeldahl method, give a value of $4.9 \mathrm{gm}$. per 100 c.c. of serum for premature babies, $5 \cdot 52 \mathrm{gm}$. per 100 c.c. for normal newborn babies and $6.29 \mathrm{gm}$. per 100 c.c. for children of five to eight months of age. Rennie (1935) gives a range of 6.04 to $8.0 \mathrm{gm}$. per 100 c.c. of serum for apparently normal children three to twenty-three months of age with an average of $7.08 \mathrm{gm}$. per 100 c.c. He states that the figures for infants over three months of age and for older children show little difference either in range or average.'
No doubt some of these differences have arisen owing to the use of different methods of estimation. For instance, it has been established that a refractometer method gives somewhat higher values than Kjeldahl estimations and this discrepancy between the two methods is increased if the plasma is lipaemic.

In this note the plasma protein values of a hundred and eighty normal full-term infants and young children and of twenty premature infants are reported. Many of these children were attending infant welfare centres. Those under two weeks of age were in a maternity hospital. Estimations were made by the micro-Kjeldahl method followed by Nesslerization. Only 0.01 c.c. of plasma was used which was obtained from a heel prick and collected over heparin in a micro-test-tube. The results of these estimations are recorded graphically, those for premature infants being separated from those of full-term infants. For comparative purposes some estimations were made on normal adults, the same method being used and the blood being collected from the lobe of the ear. These results are shown in a separate column.

From the figures thus obtained the following deductions can be drawn:

(1) In the first two weeks of life, the full-term

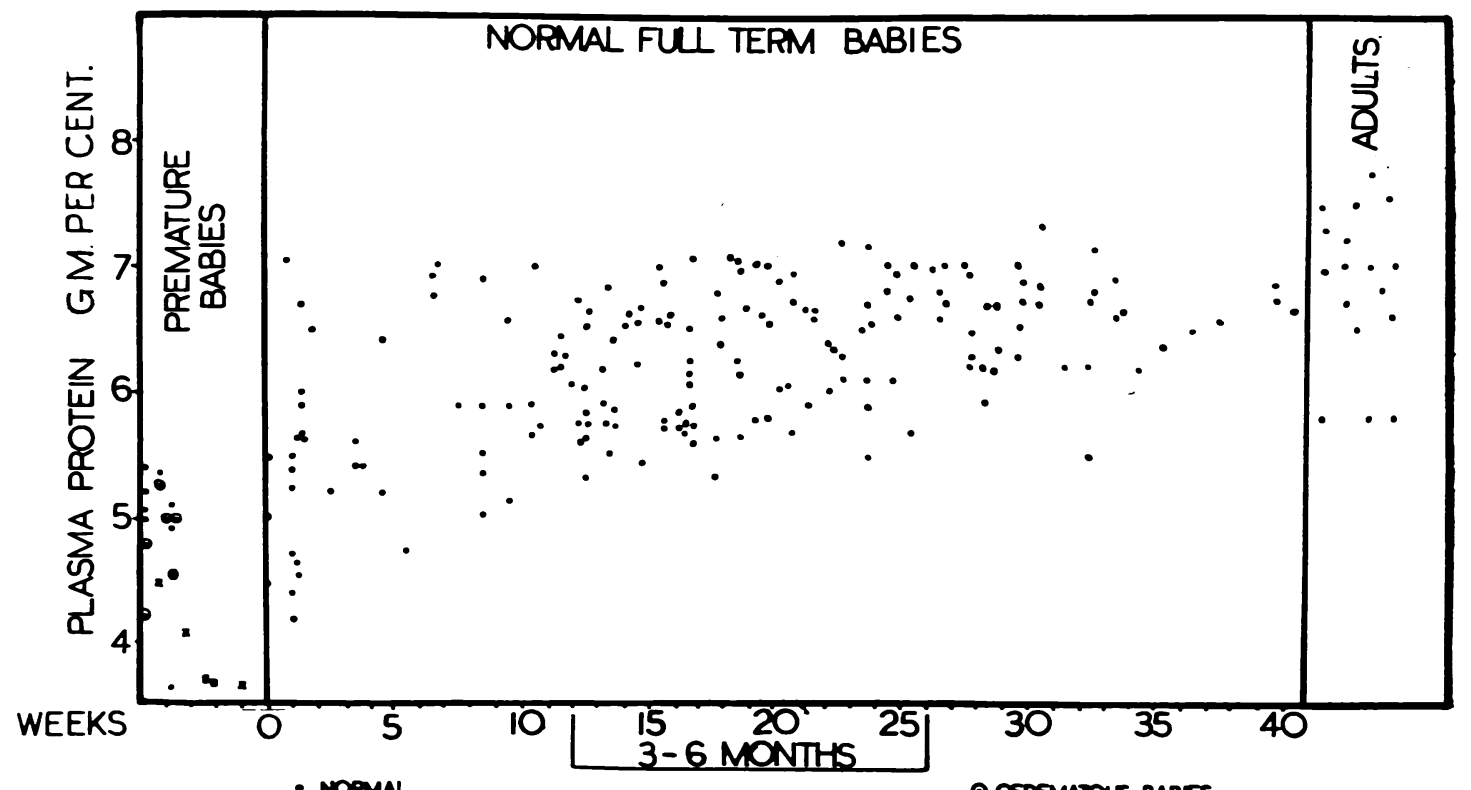

$X$ PATENT A. AN DTFERENT ACES

Fig. 1. 
infant may have a plasma protein value of from 4 to $7 \mathrm{gm}$. per 100 c.c. In the majority of instances in this series the plasma protein is below $6 \mathrm{gm}$. per 100 c.c.

(2) The values for premature infants in the first four weeks of life are somewhat lower, and range from 3.7 to $5.4 \mathrm{gm}$. per 100 c.c. In two infants from whom blood was taken on several occasions, the value decreased.

(3) The range for full-term infants over two to three weeks old is from 4.7 to $7 \cdot 4 \mathrm{gm}$. per 100 c.c.

(4) In infants over ten weeks of age, most of the values lie in the upper half of this range, viz. between 6 and $7.4 \mathrm{gm}$. per 100 c.c. The majority of the figures for adults recorded here also lie within this somewhat more limited range but sometimes reach higher figures than any observed in this series of infants.

It is interesting to note that McCarthy (1938) reports two observations on the total protein concentration in un-dialysed serum of two maternal sheep and their lambs. The figure obtained for lamb 2 was 4.89 per cent. and sheep 2 was 7.98 per cent.
Another lamb serum had a protein concentration of 4.34 per cent. and the corresponding maternal serum contained 6.61 per cent. These findings have not yet been fully explained.

\section{Summary}

Premature infants particularly, and normal fullterm infants up to two to three weeks of age show a lower plasma protein value than infants from three weeks of age to nearly one year. In infants over three weeks old, the values approach closely to those obtained from normal adults.

The expenses of this work have been partly defrayed by the Medical Research Council to whom thanks are due.

\section{REFERENCES}

Darrow, D. C., and Cary, M. K. (1933). J. Pediat., 3, 573.

Kylin, E. (1932). Acta paediatr. Stockh., 14, 160.

McCarthy. E. F. (1938). J. Phisiol.. 93, 81.

Ray, H. H., and Phatak, N. M. (1930). Amer. J. Dis. Child. . 40, 549.

Rennie, J. B. (1935). Arch. Dis. Childh., 10, 415. 